\title{
The Preparation and Identification of Characteristic Flavour Compounds of Maillard Reaction Products of Protein Hydrolysate from Grass Carp (Ctenopharyngodon idella) Bone
}

\author{
Yunliang Li $\mathbb{D}^{1},{ }^{1}$ Xiaojing Wang $\mathbb{D}^{1},{ }^{1}$ Yang Xue $\mathbb{D}^{2},{ }^{2}$ Siyu Ruan $\mathbb{D}^{1},{ }^{1}$ Anqi Zhou $\mathbb{D}^{1}$ \\ Shanfeng Huang $\mathbb{D}^{1}{ }^{1}$ and Haile $M a \mathbb{D}^{1}$ \\ ${ }^{1}$ Key Laboratory of Food Processing in Jiangsu Province of China, School of Food and Biological Engineering, Jiangsu University, \\ 301 Xuefu Road, Zhenjiang, Jiangsu 212013, China \\ ${ }^{2}$ Department of Basic Medicine, Chengde Medical University, Anyuan Road, Chengde, Hebei 067000, China
}

Correspondence should be addressed to Yunliang Li; liyunliang@ujs.edu.cn and Yang Xue; yangxue19891012@163.com

Received 7 April 2021; Accepted 27 April 2021; Published 7 May 2021

Academic Editor: Shengbao Cai

Copyright (c) 2021 Yunliang Li et al. This is an open access article distributed under the Creative Commons Attribution License, which permits unrestricted use, distribution, and reproduction in any medium, provided the original work is properly cited.

This study aims at preparing the Maillard reaction products of protein hydrolysate from grass carp (Ctenopharyngodon idella) bone and identifying its characteristic flavour compounds. Meanwhile, bioactivities and amino acids composition of hydrolysates and its Maillard reaction products were compared with the thermal degradation reaction as one positive control. Single factor experiment was applied to optimize the enzymolysis parameters of grass carp bone protein using flavourzyme, under which the highest degree of hydrolysis (40.1\%) was obtained. According to the response surface methodology, the top predicted value $(70.45 \%)$ of degree of graft of Maillard reaction was obtained with initial pH of 7.07, temperature of $118.33^{\circ} \mathrm{C}$, and time of $1.75 \mathrm{~h}$. Moreover, the results of Maillard reaction products illustrated a significant increase in DPPH radical scavenging activity $(p<0.05)$ compared to that of hydrolysate and its thermal degradation products, which was accompanied by the decreased ACE inhibitory activity. Besides, the umami-sweet taste amino acid ratio in free amino acids of Maillard reaction products climbed considerably compared to those of hydrolysate and its thermal degradation products, which proved that Maillard reaction is an effective way to improve the flavour taste of protein hydrolysate. The GC-MS results showed that 37, 40, and 62 kinds of volatile compounds were detected in hydrolysate, thermal degradation products, and Maillard reaction products, respectively. The Maillard reaction products contained more flavour volatile compounds of aldehydes, alcohol, ketone, pyrazine, and other compounds that contribute to pleasant aromas. These results suggested that the grass carp bone protein hydrolysate after Maillard reaction could potentially have a wide range of applications as antioxidant and flavour substances.

\section{Introduction}

As a traditional freshwater fish, grass carp (Ctenopharyngodon idellus) is one of the major freshwater-cultured fishes [1]. Its production comprises up to $35 \sim 40 \%(3.7$ million tons annually) of the total freshwater fish species [2] and it is widely popular with consumers for its palatability, nutritional characteristic, and low price $[1,3]$. Therefore, it would not be a surprise that there are various categories of intensive processing products for grass carp in contemporary society, such as fish ball, fish noodle, and fish tofu. With the rapid growth of the fish products industry, the amount of fish bones rich in nutrition, such as protein, fat, and minerals, also increases proportionately. However, in most circumstances, these high-quality resources of nutrition are merely used as animal feed additives and fertilizer or buried directly, which is regarded to be a waste. Therefore, it is of great urgency to develop value-added products from grass carp bone.

The application of enzymolysis technology has attracted considerable interest in the conversion of underutilized resource into a more marketable and functional form, which can promote the physicochemical, functional, and sensory properties of the native protein [4]. Researches showed that 
the grass carp proteins were mainly used to prepare bioactive peptide and functional material in secondary processing $[5,6]$. For example, the research of Li et al. [7] revealed that the grass carp protein hydrolysate displayed high antioxidant activities. What is more, Wang et al. [8] claimed that grass carp peptides associated with NO regulation and the rennin-angiotensin system present to have antihypertensive effect. In other researches, fish protein hydrolysate was proved to be of use for flavour enhancer for direct human consumption for the material composition of free amino acids, smaller peptides, salt, and many savory compounds [9]. However, the study of protein hydrolysate from grass carp bone on food flavour agents has not been fully investigated.

The flavour of protein hydrolysate is related to the type of protease and enzymatic condition, among which bitter taste is the major problem affecting the sensory acceptability of protein hydrolysate. Some methods exist to limit the formation of bitter compounds during hydrolysis, such as controlling degree of hydrolysis (DH), choosing some specific enzymes, and masking by cyclodextrin [10]. The choice of protease affects the functional and flavour characteristics of protein hydrolysate. Flavourzyme is one commonly used protease in various commercial proteases to produce low-bitter flavour peptide compounds. It is endoand exopeptidase enzymes mixture, which can effectively minimize the bitterness produced by the previous hydrolysis in the hydrolyzed peptide product [11]. It can hydrolyze proteins and produce more flavour peptides as well as amino acids for the product, which is more suitable for the hydrolysis of seafood. Also, recent studies show that a higher $\mathrm{DH}$ is more conducive to the formation of flavour amino acids and potential flavouring material $[11,12]$. Therefore, it is an effective method to produce hydrolysate using flavourzyme under longer enzymatic time from grass carp bone protein (GCBP).

Besides, the Maillard reaction has also been reported to be an effective method to improve the functional properties of protein hydrolysate [13], masks the initial fish off-flavours, and improves the odour characteristics of hydrolysates [14]. Other researches regard that the peptides with smaller molecular weight showed a higher reaction degree to produce more characteristic flavour compounds through Maillard reaction [15]. According to these researches, it can be concluded that enzymolysis of protein and Maillard reaction of protein hydrolysate were two effective methods for preparing flavour compounds. However, which one is beneficial for making full use of grass carp bone is still uncertain.

Therefore, the objective of this study was to demonstrate the use of by-products of the fish industry (fish bone) for the generation of bioactive substances and fish flavour compounds. The content includes the three following contents: (1) to optimize enzymatic parameters of GCBP and Maillard reaction conditions of GCBP hydrolysate, (2) to investigate the bioactivities of GCBP hydrolysate and its Maillard reaction products with the thermal degradation reaction as one positive control, and (3) to analyze and compare the flavour components of the GCBP hydrolysate and its
Maillard reaction products with the thermal degradation reaction as one positive control. It is also hoped that the results of the present research will be of great value to the application of grass carp bone and even other fish bones.

\section{Materials and Methods}

2.1. Materials. Grass carp (Ctenopharyngodon idella) bone was provided by a fish market of Zhenjiang, Jiangsu, China. Flavourzyme (activity of $2.44 \times 10^{4} \mathrm{U} / \mathrm{mg}$ ) was purchased from Novozymes Co. Ltd. (China). Angiotensin-I-converting enzyme (ACE) was extracted from the pig lung according to the reported method (Maruyama et al., 1999). N-[3-(2-Furyl)-acryloyl]-L-phenylalanyl-glycyl-glycine (FA PGG), 1,1-Diphenyl-2-picrylhydrazyl (DPPH), and 4-(2Hydroxyethyl)piperazine-1-ethanesulfonic acid (HEPES) were purchased from Sigma-Aldrich Corp. (USA). All the other chemicals and solvents used in the experiment were of analytical grade.

2.2. Extraction of Fish Bone Protein. In this study, alkali extraction combined with high-temperature treatment was applied to improve protein purity. Briefly, the fresh fish bone with a few of meat (byproduct of fish balls) was washed by using running water and then chopped into pieces $(\sim 0.3 \mathrm{~cm})$ homogenized with water $(w / v, 1: 4.5)$ and the mixture was adjusted to $\mathrm{pH} 9.0$ by adding $2 \mathrm{~mol} / \mathrm{L} \mathrm{NaOH}$. Afterwards, the mixture was placed in high-pressure cooking machine at $120^{\circ} \mathrm{C}$ for $60 \mathrm{~min}$. The homogenate was cooled to room temperature and centrifuged for $20 \mathrm{~min}$ at 5,000 r/min. The insoluble pellets and grease suspensions were discarded. Soluble protein in the supernatant was frozen-dried to prepare fish bone protein powder. The protein content of the fish bone powder was assayed by the Kjeldahl method (AOAC 991.20) and the value was 92.38\% (dry weight).

\subsection{Screening of Enzymolysis Conditions of Fish Bone Protein.} In order to optimize enzymolysis conditions of fish bone protein for the maximum $\mathrm{DH}$, single factor experimental design was employed. The fish bone powder was mixed with distilled water and then the mixture was hydrolyzed with flavourzyme according to the enzymatic conditions defined by the experimental design with $\mathrm{DH}$ as an index. The single factor experiment was conducted under the following conditions: substrate concentration of $20,30,40,50$, and $60 \mathrm{~g} / \mathrm{L} ; \mathrm{pH}$ value of $6,6.5,7,7.5$, and 8 ; temperature of 40,45 , 50,55 , and $60^{\circ} \mathrm{C}$; enzyme-to-substrate ratio of $5 \%, 5.5 \%, 6 \%$, $6.5 \%, 7 \%$, and $7.5 \%$; and enzymolysis time of $5,6,7,8$, and $9 \mathrm{~h}$. The reaction was terminated by boiled water bath for $15 \mathrm{~min}$ to inactivate the enzyme. Then the sample was centrifuged for $15 \mathrm{~min}$ at $4000 \mathrm{r} / \mathrm{min}$ after cooling to the room temperature $\left(25 \pm 1^{\circ} \mathrm{C}\right)$. The supernatant of protein hydrolysate was used for further analysis. All reactions were operated in triplicate.

2.4. Determination of Degree of Hydrolysis. $\mathrm{DH}$ is defined as the percentage of the number of peptide bonds broken to the 
total number of bonds per unit weight, which was calculated from the ratio of $\alpha$-amino nitrogen to total nitrogen. The amino nitrogen content was determined by a formaldehyde titration method [16]. An equal amount of distilled water was added to $10 \mathrm{~mL}$ supernatant of protein hydrolysate (Section 2.3) and the mixture was adjusted to $\mathrm{pH} 7.0 \mathrm{using} 0.1 \mathrm{~mol} / \mathrm{L}$ $\mathrm{NaOH}$. Then $10 \mathrm{~mL}$ of $38 \%(v / v)$ formaldehyde solution was added to the mixture and titration was continued to the end point at $\mathrm{pH} 9.5$ with $0.2 \mathrm{~mol} / \mathrm{L}$ standard $\mathrm{NaOH}$ solution. The total nitrogen content was determined by Kjeldahl method (AOAC 991.20). Tests were conducted in triplicate.

2.5. Optimization of Maillard Reaction Condition. Based on the optimal protein enzymolysis condition (Section 2.3), the supernatant of the grass carp bone protein hydrolysate was prepared for Maillard reaction. According to our previous experiment results, the supernatant of protein hydrolysate was mixed with glucose of $4 \%(w / v)$, glycine-arginine (ratio of $1: 1)$ mixture of $3 \%(w / v)$, vitamin C of $0.15 \%(w / v)$, and vitamin $\mathrm{B}_{1}$ of $0.05 \%(w / v)$. Then the sample (protein concentration of $1 \mathrm{mg} / \mathrm{mL}$ ) was put in sealed tube and heated for $1 \mathrm{~h}$ at $120^{\circ} \mathrm{C}$ in oil bath. The mixture was immediately cooled in ice bath for $30 \mathrm{~min}$ to terminate Maillard reaction. Then Maillard reaction products (MRP) were kept at $-20^{\circ} \mathrm{C}$ for further analysis.

The initial $\mathrm{pH}\left(X_{1}\right)$, reaction temperature $\left(X_{2}\right)$, and reaction time $\left(X_{3}\right)$ were found to have significant influences on Maillard reaction by one-way analysis of variance. In order to optimize the reaction parameters, Box-Behnken design was selected and used to encode the test factors. The actual and coded values for the independent variables are shown in Table 1 . The factors with the same coded levels $(-1,0,1)$ and corresponding actual values were as follows: initial $\mathrm{pH}$ of 6 , 7 , and 8; reaction temperature of 90,110 , and $130^{\circ} \mathrm{C}$; and reaction time of 1,2 , and $3 \mathrm{~h}$. The degree of graft (DG) was an index to evaluate Maillard reaction and it was set as the response $(Y)$. Each run was conducted in triplicate. The quadratic equation was the same as that of equation (2).

The complete quadratic equation reflecting the effect of the three independent variables on the DG was shown as follows:

$$
Y=\beta_{0}+\sum_{i=1}^{3} \beta_{i} X_{i}+\sum_{i=1}^{3} \beta_{i i} X_{i}^{2}+\sum_{i=1}^{3} \sum_{j=i+1}^{3} \beta_{i j} X_{i} X_{j}
$$

where $Y$ is the response variable; $\beta_{0}$ is a constant; $\beta_{i}, \beta_{i i}$, and $\beta_{i j}$ are the regression coefficients for intercept, linearity, square, and interaction, respectively; $X_{i}$ and $X_{j}$ are the different independent variables $(i \neq j)$. To deduce the quadratic equation (1), seventeen factorial points and five replicates of the center points were designed by the BoxBehnken design (Table 1).

In order to evaluate the effects of Maillard reaction, thermal degradation reaction of protein hydrolysate was employed to be a positive control. After hydrolysis of fish bone protein, the protein hydrolysate was directly heated for $1 \mathrm{~h}$ at $120^{\circ} \mathrm{C}$ in oil bath without adding glucose, glycine-arginine mixture, vitamin $C$, and vitamin $B_{1}$ under the optimal conditions of Maillard reaction, including temperature, $\mathrm{pH}$, and time. Then the mixture was immediately cooled in ice bath for $30 \mathrm{~min}$ to terminate the heat reaction. The thermal degradation products (TDP) were stored at $-20^{\circ} \mathrm{C}$ for further analysis. All trials were performed in triplicate.

2.6. Determination of the DG. The DG value was determined by o-phthaldialdehyde method [17] with light modifications. The preparation method of o-phthaldialdehyde reagent was as follows: $40 \mathrm{mg}$ of o-phthaldialdehyde was dissolved in $1.0 \mathrm{~mL}$ of methanol, $25 \mathrm{~mL}$ sodium tetraborate $(0.1 \mathrm{~mol} / \mathrm{L})$, $2.5 \mathrm{~mL}$ sodium dodecyl sulfate $(20 \%, w / w)$, and $100 \mu \mathrm{L}$ of $\beta$-mercaptoethanol. Then the mixture was diluted to a final volume of $50 \mathrm{~mL}$ with distilled water, after which two hundred microliter sample solution (protein concentration of $1 \mathrm{mg} / \mathrm{mL}$ ) was added to $4 \mathrm{~mL}$ o-phthaldialdehyde reagent. The solution was mixed briefly and incubated for $2 \mathrm{~min}$ at $37^{\circ} \mathrm{C}$. The absorbance was read at $340 \mathrm{~nm}$ using a spectrophotometer (Unic 7200, Unocal Corporation, Shanghai, China). Tests were performed in triplicate, and DG was calculated according to the following formula:

$$
\operatorname{DG}(\%)=\frac{A_{0}-A_{1}}{A_{0}} \times 100 \% \text {, }
$$

where $A_{0}$ was the absorbance of the supernatant of protein hydrolysate at $340 \mathrm{~nm} ; A_{1}$ was the absorbance of mixture after Maillard reaction at $340 \mathrm{~nm}$.

\subsection{DPPH Radical Scavenging Activity and ACE Inhibitory} Activity Assays. The DPPH radical scavenging activity was measured by the method of Nasrollahzadeh et al. [18] with some modifications. $2 \mathrm{~mL}$ of $\mathrm{DPPH}$ solution $(0.1 \mathrm{~mol} / \mathrm{L}$, dissolved in methanol) was added to $2 \mathrm{~mL}$ of sample (protein concentration of $1 \mathrm{mg} / \mathrm{mL}$ ). Then the mixture was kept in the dark for $20 \mathrm{~min}$ at $37^{\circ} \mathrm{C}$, followed by the centrifugation for $10 \mathrm{~min}$ at $4000 \mathrm{r} / \mathrm{min}$ and the measurement of the absorbance at $517 \mathrm{~nm}$ using spectrophotometer (Unic 7200, Unocal Corporation, Shanghai, China). The blank and control were prepared with the distilled water instead of samples and methanol instead of DPPH solution, respectively. All reactions were operated in triplicate. The DPPH radical scavenging activity was calculated by the following formula:

$$
\text { DPPH radical scavenging rate }(\%)=\left(1-\frac{A_{1}-A_{2}}{A_{0}}\right) \times 100 \% \text {, }
$$

where $A_{0}$ is the absorbance of the blank (methanol instead of the sample), $A_{1}$ is the absorbance of sample, and $A_{2}$ is the background absorbance (methanol instead of DPPH).

The ACE activity was measured following the method of Zhou et al. [19] with some modifications. The samples were diluted 100 times with a HEPES buffer $(80 \mathrm{mmol} / \mathrm{L}, \mathrm{pH} 8.3$, $300 \mathrm{mmol} / \mathrm{L} \mathrm{NaCl})$. The reaction mixture contained $50 \mu \mathrm{L}$ ACE, $100 \mu \mathrm{L}$ sample, and $50 \mu \mathrm{L}$ FAPGG $(1.0 \mathrm{mmol} / \mathrm{L})$. The control was prepared with HEPES buffer instead of samples. After being incubated for $30 \mathrm{~min}$ at $37^{\circ} \mathrm{C}$, the mixture was 
TABLE 1: Box-Behnken design and results of Maillard reaction of protein hydrolysate from grass carp bone.

\begin{tabular}{|c|c|c|c|c|c|}
\hline Level & $X_{1}$ & $X_{2}$ & $X_{3}$ & & $Y$ \\
\hline 1 & $-1(6)$ & $-1(90)$ & $0(2)$ & & 36.52 \\
\hline 2 & $1(8)$ & $-1(90)$ & $0(2)$ & & 41.33 \\
\hline 3 & $-1(6)$ & $1(130)$ & $0(2)$ & & 50.08 \\
\hline 4 & $1(8)$ & $1(130)$ & $0(2)$ & & 53.89 \\
\hline 5 & $-1(6)$ & $0(110)$ & $-1(1)$ & & 47.62 \\
\hline 6 & $1(8)$ & $0(110)$ & $-1(1)$ & & 53.14 \\
\hline 7 & $-1(6)$ & $0(110)$ & $1(3)$ & & 39.17 \\
\hline 8 & $1(8)$ & $0(110)$ & $1(3)$ & & 39.82 \\
\hline 9 & $0(7)$ & $-1(90)$ & $-1(1)$ & & 56.33 \\
\hline 10 & $0(7)$ & $1(130)$ & $-1(1)$ & & 60.31 \\
\hline 11 & $0(7)$ & $-1(90)$ & $1(3)$ & & 42.24 \\
\hline 12 & $0(7)$ & $1(130)$ & $1(3)$ & & 59.30 \\
\hline 13 & $0(7)$ & $0(110)$ & $0(2)$ & & 66.04 \\
\hline 14 & $0(7)$ & $0(110)$ & $0(2)$ & & 68.17 \\
\hline 15 & $0(7)$ & $0(110)$ & $0(2)$ & & 69.42 \\
\hline 16 & $0(7)$ & $0(110)$ & $0(2)$ & & 67.36 \\
\hline 17 & $0(7)$ & $0(110)$ & $0(2)$ & & 64.88 \\
\hline \multicolumn{6}{|l|}{$R^{2}=0.9891$} \\
\hline Term & Sum of squares & Df & Mean square & $F$-value & $p$ value \\
\hline Model & 2013.44 & 9 & 223.72 & 70.68 & $<0.0001$ \\
\hline$X_{1}$ & 916.04 & 1 & 916.04 & 289.41 & $<0.0001$ \\
\hline$X_{2}$ & 108.89 & 1 & 108.89 & 34.40 & 0.0006 \\
\hline$X_{3}$ & 6.29 & 1 & 6.29 & 1.99 & 0.2014 \\
\hline$X_{1} X_{2}$ & 0.25 & 1 & 0.25 & 0.079 & 0.7868 \\
\hline$X_{1} X_{3}$ & 5.93 & 1 & 5.93 & 1.87 & 0.2134 \\
\hline$X_{2} X_{3}$ & 42.77 & 1 & 42.77 & 13.51 & 0.0079 \\
\hline$X_{1} X_{1}$ & 1033.00 & 1 & 1033.00 & 326.36 & $<0.0001$ \\
\hline$X_{2} X_{2}$ & 154.41 & 1 & 154.41 & 48.78 & 0.0002 \\
\hline$X_{3} X_{3}$ & 181.93 & 1 & 181.93 & 57.48 & 0.0001 \\
\hline Residual & 22.16 & 7 & 3.17 & & \\
\hline Lack of fit & 9.54 & 3 & 3.18 & 1.01 & 0.4763 \\
\hline Pure error & 12.62 & 4 & 3.15 & & \\
\hline Sum & 2035.59 & 16 & & & \\
\hline
\end{tabular}

measured in the absorption at $340 \mathrm{~nm}$. The ACE inhibitory activity was calculated using the following formula:

$$
\text { ACE inhibitory activity }(\%)=1-\frac{A_{s 0}-A_{s 30}}{A_{b 0}-A_{b 30}} \times 100 \% \text {, }
$$

where $A_{s 0}$ and $A_{s 30}$ represent the absorption of sample at $0 \mathrm{~min}$ and $30 \mathrm{~min}$. $A_{b 0}$ and $A_{b 30}$ represent the absorption of blank at $0 \mathrm{~min}$ and $30 \mathrm{~min}$.

2.8. Determination of Amino Acids Composition. The total amino acids profile of grass carp bone protein hydrolysates (GCBPH), thermal degradation products (TDP), and Maillard reaction products (MRP) was determined using an amino acid analyzer (S433D, Sykam, German) after hydrolyzing under vacuum with $6 \mathrm{~mol} / \mathrm{L} \mathrm{HCl}$ at $110^{\circ} \mathrm{C}$ for $24 \mathrm{~h}$ in the presence of $1 \%$ phenol $(v / v)$. The free amino acid (FAA) profile was measured directly by the analyzer. The peptide-bound amino acid was calculated by subtracting FAA from total amino acid (TAA) [20]. The results were expressed as $\mathrm{mg} / \mathrm{g}$ dry weight of products.

2.9. Determination of Volatile Compounds by Dynamic Headspace Gas Chromatography-Mass Spectrometry. The volatile compounds in GCBPH, TDP, and MRP were detected using HP6890/5973 dynamic headspace gas chromatographymass spectrometry (DHS GC-MS) (Agilent Technologies (China) Co., Ltd.) [21] with some modifications. Each sample was prepared from $4 \mathrm{~mL}$ of samples (GCBPH, TDP, and MRP) and $1.0 \mathrm{~g}$ of $\mathrm{NaCl}$ in a $15 \mathrm{~mL}$ vial for the headspace technique. During the headspace collection procedure, samples were magnetically stirred at $600 \mathrm{r} / \mathrm{m}$ and equilibrated for $40 \mathrm{~min}$ at $60^{\circ} \mathrm{C}$ after purging the nitrogen. The separation of volatile compounds was achieved on a DB-WAX capillary column $(60 \mathrm{~mm} \times 0.25 \mathrm{~mm} \times 0.25 \mu \mathrm{m})$. Helium was used as carrier gas at a flow rate of $0.8 \mathrm{~mL} / \mathrm{min}$. Oven initial temperature was set at $120^{\circ} \mathrm{C}$ for $4 \mathrm{~min}$ and then programmed to $90^{\circ} \mathrm{C}$ by a temperature ramp of $5^{\circ} \mathrm{C} / \mathrm{min}$ and lastly increased to $210^{\circ} \mathrm{C}$ at $10^{\circ} \mathrm{C} / \mathrm{min}$ with a final isothermal period of $10 \mathrm{~min}$. The inlet and interface temperature were both kept at $250^{\circ} \mathrm{C}$. A mass spectrometer scanned from 33 to $450 \mathrm{u}$. The ion source was set at $200^{\circ} \mathrm{C}$ and spectra were obtained by electron impact $(70 \mathrm{eV})$.

In this experiment, the compound standards of $\mathrm{C}_{7} \sim \mathrm{C}_{30}$ were selected for qualitative analysis and 2,4,6-trimethy lpyridine (chromatographic purity) was used as internal standard for quantitative analysis. The results were expressed as the relative area percentages being indices of the mass percentages of the compounds. 
2.10. Statistical Analysis. The data were expressed as means \pm standard differences. Results were statistically analyzed to identify differences by using one-way ANOVA and the Duncan test under the significance level of $p<0.05$ using SPSS 19.0 software (IBM Corporation, NY, USA). Design expert 8.0.5b (Trial Version, State-Ease, Inc., Minneapolis, MN, USA) software package was used to analyze the experimental data of Box-Behnken design.

\section{Results}

3.1. Single Factor Experimental Results of Enzymolysis of Grass Carp Bone Protein. In order to determine the optimal levels of each variable of enzymolysis conditions for maximum $\mathrm{DH}$, single factor experimental design was employed. Figures 1(a)1 (e) show the $\mathrm{DH}$ of grass carp bone protein at different substrate concentration $(20 \sim 60 \mathrm{~g} / \mathrm{L}), \mathrm{pH}$ value $(6.0 \sim 8.0)$, temperature $\left(40 \sim 60^{\circ} \mathrm{C}\right)$, enzyme-to-substrate ratio $(5.5 \sim 7.5 \%)$, and enzymolysis time $(5 \sim 9 \mathrm{~h})$. When screening the first parameter (substrate concentration), other parameters were set as follows: $\mathrm{pH}$ value of 7.0, temperature of $50^{\circ} \mathrm{C}$, enzyme-to-substrate ratio of $6.5 \%$, and enzymolysis time of $5 \mathrm{~h}$. The following parameters were optimized using the best condition selected previously.

The effects of substrate concentration on the $\mathrm{DH}$ of grass carp bone protein are shown in Figure 1(a). As reflected in the results, $\mathrm{DH}$ and the substrate concentration showed a reversed trend and those of $20 \mathrm{~g} / \mathrm{L}$ (with the DH value of $21.55 \%$ ) and $30 \mathrm{~g} / \mathrm{L}$ (with the value of $20.99 \%$ ) had no significant difference. To obtain more hydrolysates, $30 \mathrm{~g} / \mathrm{L}$ was selected to optimize the following enzymatic parameters. As shown in Figure 1(b), the results showed that different $\mathrm{pH}$ values influenced $(p<0.05)$ the $\mathrm{DH}$ of grass carp bone protein to a great extent and the highest DH (23.54\%) was obtained when the $\mathrm{pH}$ was 7.5 , which was selected to optimize the following enzymatic parameters. Similar to that of $\mathrm{pH}$ value, the $\mathrm{DH}$ of grass carp bone protein significantly $(p<0.05)$ increased and then decreased with the elevated enzymatic temperature (Figure 1(c)). At the temperature of $50^{\circ} \mathrm{C}$, the highest $\mathrm{DH}$ of $23.54 \%$ was obtained. The $\mathrm{DH}$ increased significantly $(p<0.05)$ with the increase in enzymeto-substrate ratio and that of $7.0 \%$ and $7.5 \%$ had no significant difference $(p>0.05)$ (Figure 1(d)). In order to reduce the cost, enzyme-to-substrate ratio of $7.0 \%$ was used to optimize the following parameter. As for enzymatic time, the $\mathrm{DH}$ of grass carp bone protein increased gradually with its extension. However, the data of $8 \mathrm{~h}$ had no significant effect $(p>0.05)$ compared to that of $9 \mathrm{~h}$. Therefore, enzymatic time of $8 \mathrm{~h}$ was selected.

Enzymatic parameters afforded by this study produced different influence on the $\mathrm{DH}$ of grass carp bone protein. The optimal enzymatic conditions were as follows: substrate concentration of $30 \mathrm{~g} / \mathrm{L}, \mathrm{pH}$ value of 7.5 , enzymatic temperature of $50^{\circ} \mathrm{C}$, enzyme-to-substrate ratio of $7.0 \%$, and enzymatic time of $8 \mathrm{~h}$. Under these conditions, the $\mathrm{DH}$ of grass carp bone protein reached the highest value of $40.1 \%$.

3.2. Response Surface Results of Maillard Reaction of Grass Carp Bone Protein Hydrolysates (GCBPH). In order to determine the optimal levels of each variable of Maillard reaction conditions for maximum DG, Box-Behnken design was employed to determine their optimal levels. The design matrix and the DG of the Maillard reaction are shown in Table 1. Multiple regression analysis was used to analyze the data and thus a quadratic polynomial equation was derived from regression analysis as follows:

$$
\begin{aligned}
Y=- & 936.65+224.94 X_{1}+3.39 X_{2}+12.22 X_{3}-0.013 X_{1} X_{2} \\
& -1.22 X_{1} X_{3}+0.16 X_{2} X_{3}-15.66 X_{1} X_{1}-0.015 X_{2} X_{2} \\
& -6.57 X_{3} X_{3} .
\end{aligned}
$$

The analysis of variance, goodness of fit, and the adequacy of the regression model are summarized in Table 1. The statistical significance of equation (5) was checked by F-test, and the results of analysis of variance indicated that the $F$-value of $70.68(p<0.0001)$ implied that the model was statistically highly significant. The $F$-value and $p$ value of the lack of fit were 1.01 and 0.4763 , respectively. This illustrated that the lack of fit was not significant, which confirmed the goodness of fit and hence suitability of the regression model for predicting the DG of Maillard reaction of GCBPH under any combination of values of the independent variables. The coefficient of multiple determinations $\left(R^{2}\right.$ of 0.9891$)$ revealed that $98.91 \%$ of the variation in the DG was due to the independent variables and only $1.09 \%$ of the total variation was not explained by the model. Table 1 also demonstrates that the independent variables $\left(X_{1}, X_{2}\right)$ exerted significant effects on DG within a 95\% confidence interval $(p<0.05)$. The quadratic terms $\left(X_{1} X_{1}, X_{2} X_{2}\right.$, and $\left.X_{3} X_{3}\right)$ as well as the interaction terms $\left(X_{2} X_{3}\right)$ were also significant. Parity plot (Figure 2 ) showed an acceptable level of agreement. The strong correlation between the actual and the predicted results confirmed that the response model was accurate to reflect the expected optimization. All these results confirmed the predictability of the model for DG of Maillard reaction of GCBPH.

The response surface and contour plots drawn by the Box-Behnken design are shown in Figure 3, which provided a method to visualize the mutual effects of test variables at different levels and the reciprocal interactions between the test variables on the DG. The mutual interactions of initial $\mathrm{pH}\left(x_{1}\right)$ and reaction temperature $\left(x_{2}\right)$ are illustrated in Figures 3(a) and 3(b). The pattern of Figure 3(a), which witnessed a slow rise in DG at first, unexpectedly declined with the continuing increase of $\mathrm{pH}$. Effects of initial $\mathrm{pH}\left(x_{1}\right)$ and reaction time $\left(x_{3}\right)$ are illustrated in Figures $3(\mathrm{c})$ and $3(\mathrm{~d})$, which showed that, with the prolonging of reaction time, the DG changed in a certain range. What is more, the effects of reaction temperature $\left(x_{2}\right)$ and time $\left(x_{3}\right)$ are illustrated in Figures 3(e) and 3(f).

According to the results in Figure 3 and Table 1, the response surface had both the highest point and the contour of the response surface within the experimental range of the independent variables. According to the established mathematical response surface design method, the optimum conditions of Maillard reaction derived from interactions of 


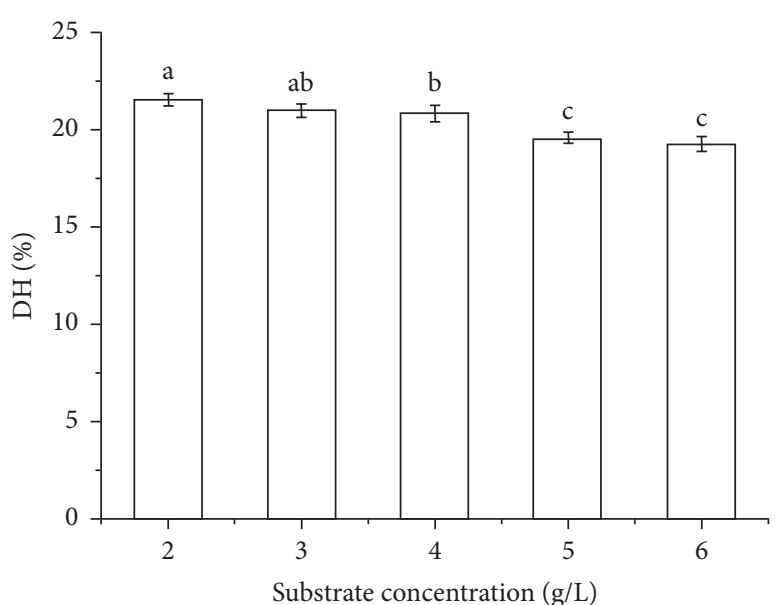

(a)

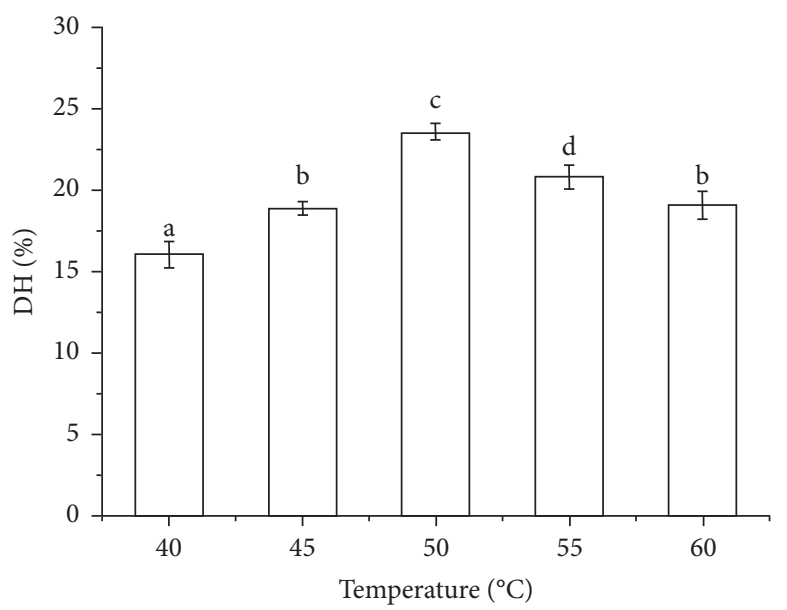

(c)

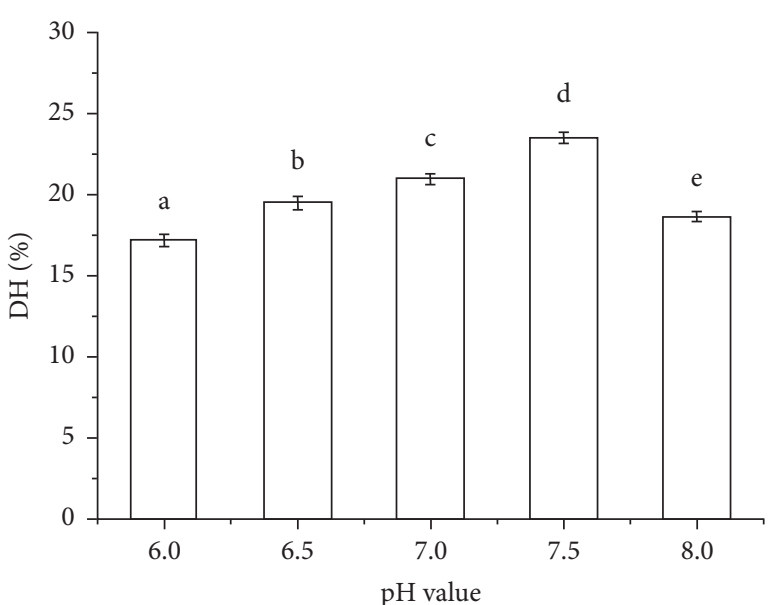

(b)

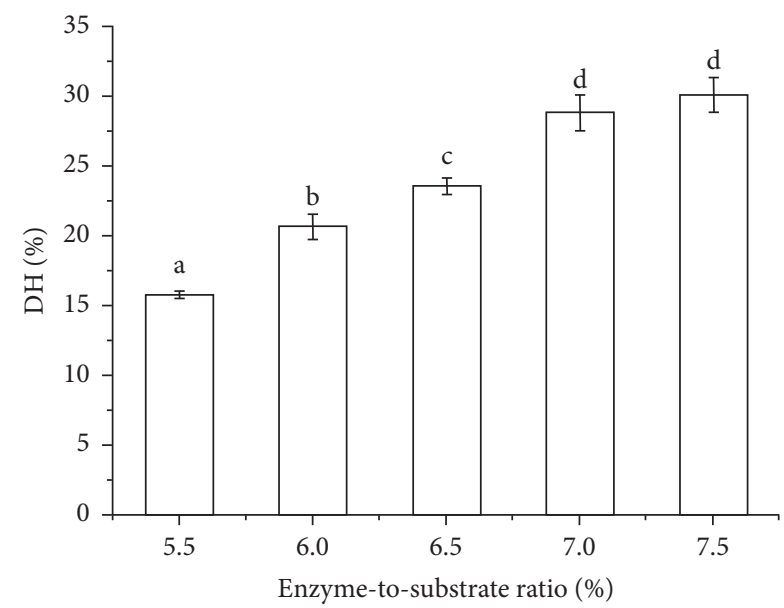

(d)

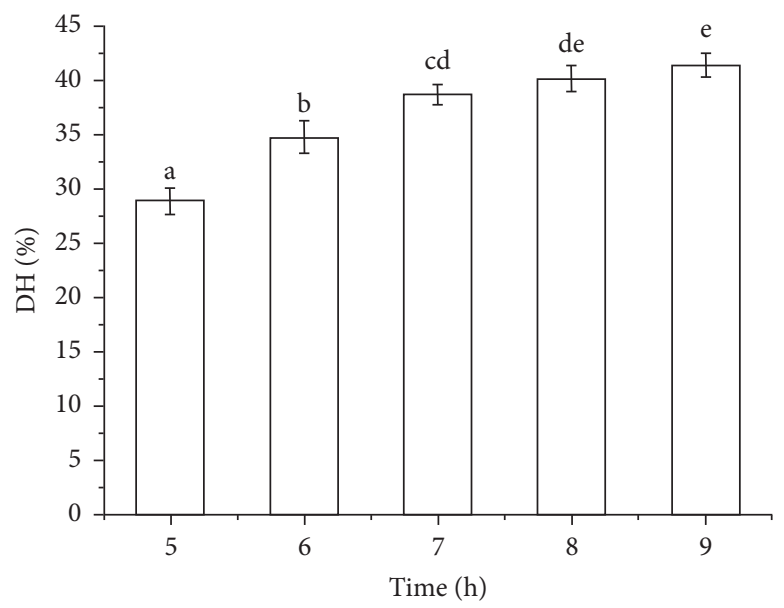

(e)

FIgURE 1: Single factor experimental results of enzymolysis conditions: (a) substrate concentration, (b) $\mathrm{pH}$ value, (c) temperature, (d) enzyme-to-substrate ratio, and (e) time. Means with different superscripts are significantly different $(p<0.05)$.

the three independent variables were initial $\mathrm{pH}$ of 7.07 , the temperature of $118.33^{\circ} \mathrm{C}$, and the time of $1.75 \mathrm{~h}$. To confirm the validity of the model, three assays were performed under the optimum conditions and the average data of three tests notified that the DG was $69.05 \%$, which was closely associated with the predicted value (70.45\%) calculated by equation (5). The strong correlation between the actual and the predicted results confirmed that the response model was accurate to reflect the expected optimization of Maillard reaction. 


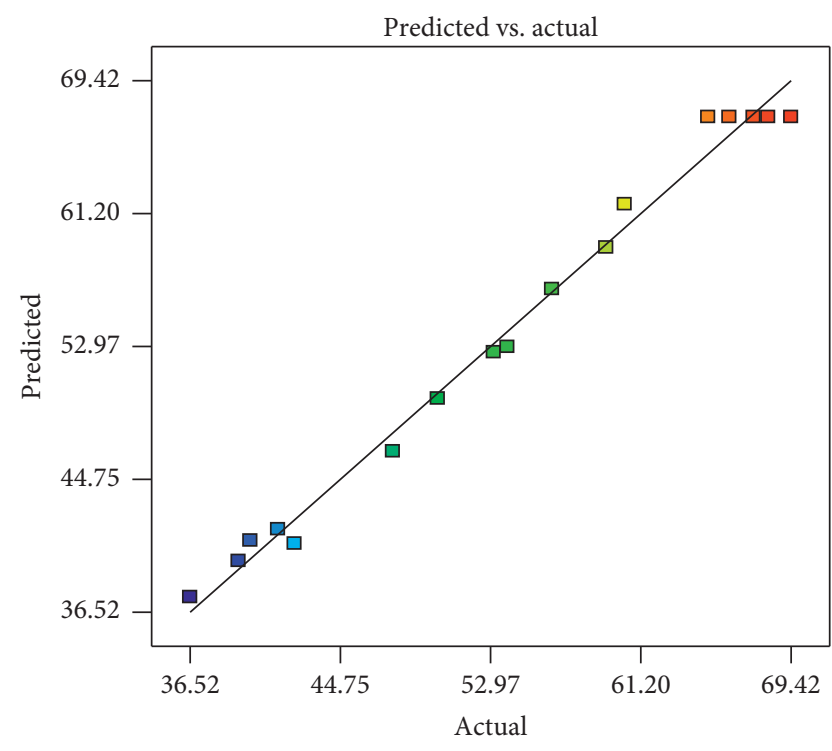

FIGURE 2: Relationship between the observed and predicted values of the degree of graft (Parity plot).

3.3. Biological Activity. Figure 4 shows the DPPH radical scavenging rate and ACE inhibitory rate of different products. The DPPH radical scavenging rate of MRP increased significantly $(p<0.05)$ compared to that of GCBPH and TDP. These results were in consistency with the literatures $[18,22]$. The reason why the antioxidant activity of MRP rose markedly may be due to the generation of increased antioxidant products during Maillard reaction rather than the thermal degradation reaction of protein hydrolysate.

The ACE inhibitory rate of MRP had no significant difference $(p>0.05)$ compared to that of GCBPH. However, the ACE inhibitory rate of TDP (with its value of $39.67 \%$ ) decreased by $8.9 \%$ in contrast to that of GCBPH, which indicated that thermal degradation methods reduced the ACE inhibitory activity of protein hydrolysate significantly $(p<0.05)$. The reason might be that thermal treatment degraded some of the active proteins or peptides into inactive fragment. Furthermore, Maillard reaction could generate more compounds and substances with strong ACE inhibitory activities, which resulted in no difference of $\mathrm{ACE}$ inhibitory activity between MRP and GCBPH.

3.4. Amino Acid Composition. The selectivity and specificity of flavourzyme to hydrolyze the fish bone protein resulted in a considerable amount of peptide and amino acids production. Amino acids were highly correlated with taste characteristics in foods peptides and related to some mechanisms of functionality, such as umami taste or umami-enhancing properties $[23,24]$. The flavour peptides were a group of peptides related to the feelings of taste and smell, which would be of varying structures and length and possess unique taste properties [25]. In order to evaluate the flavour compounds of different treatment methods on the fish bone, the amino acid compositions of GCBPH, TDP, and MRP were analyzed.
The results of total amino acid and free amino acid are shown in Table 2. In GCBPH, the contents of TAA and FAA were 566.15 and $210.32 \mathrm{mg} / \mathrm{g}$, respectively, which suggested that the ratio of FAA to TAA was $37.15 \%$, of which the umami-sweet taste amino acids much lower than individual thresholds expected for Glu, Asp, and Arg accounted for $35.47 \%$ of FAA. In TDP, the total amino acid content $(505.33 \mathrm{mg} / \mathrm{g}$ ) was lower than that of GCBPH, which might result from the generation of new compound during thermal treatment. However, the FAA content and its ratio to TAA and the ratio of umami-sweet taste amino acids to FAA did not change significantly $(p>0.05)$. This might be attributed to the crack of some of the amino acids existent in peptide into free amino acid during the high-temperature treatment. In MRP, the FAA proportion of TAA slumped to $31.82 \%$ after the Maillard reaction of hydrolysate, which proved that more FAA engaged in the Maillard reaction, compared to the amino acids present in the peptide form. Among all the FAA, Lys (9.51 mg/g), Arg (11.49 mg/g)، and Leu (14.25 mg/ g) presented dominant position in Maillard reaction, which decreased by $15.14,6.16$, and $13.94 \mathrm{mg} / \mathrm{mL}$ compared to that of GCBPH, respectively. This indicated that Lys, Arg, and Leu of FAA probably were main free amino acids involved in the Maillard reaction. In addition, umami-sweet taste amino acids of FAA were of $41.32 \%$, which increased significantly $(p<0.05)$ compared to those of GCBPH. These results showed that simple heating hydrolysis did not affect the ratios of FAA and umami-sweet taste amino acids. The decreased ratio of FAA to TAA and increased ratio of umami-sweet taste amino acids to FAA were ascribed to the Maillard reaction rather than the heat treatment during reaction processing.

3.5. Volatile Compounds. The flavourzyme hydrolysis is valuable due to the large number of natural fragrances and volatile compounds produced in the hydrolysis. The role of flavourzyme is to increase the concentrations of most of the volatile compounds that are predominantly chemical families in the hydrolysate [26]. Also, Maillard reaction can modify the odour of protein hydrolysate [14]. Accordingly, the volatile compounds of GCBPH, TDP, and MRP were detected and quantified using the DHS-GC-MS technique.

Table 3 declares the total detected individual volatile compounds with 37 flavour compounds of GCBPH, which were categorized into seven groups, namely, aldehydes, alcohol, ketone, hydrocarbon, furans, phenol, and esters, where each was composed of 9, 8, 3, 5, 5, 4, and 3 individuals, respectively. Aldehydes, indicated as final oxidation products of $\omega-3$ fatty acids for seafood and marine raw materials, were important aroma compounds in food stuffs [27]. Results illustrated that pentanal, hexanal, heptanal, and 2hexenal with low threshold values were the major volatiles in hydrolysate which mainly associated with tallow aroma. Moreover, hexanal was the aldehyde with the highest relative content of $5.21 \%$, which could be resulting from a degradation process of preformed volatiles, such as 2-octenal [28]. The 2-Methyl-butanal and 3-Methyl-butanal, representing $1.56 \%$ and $2.68 \%$ of the total volatile compounds, have been 


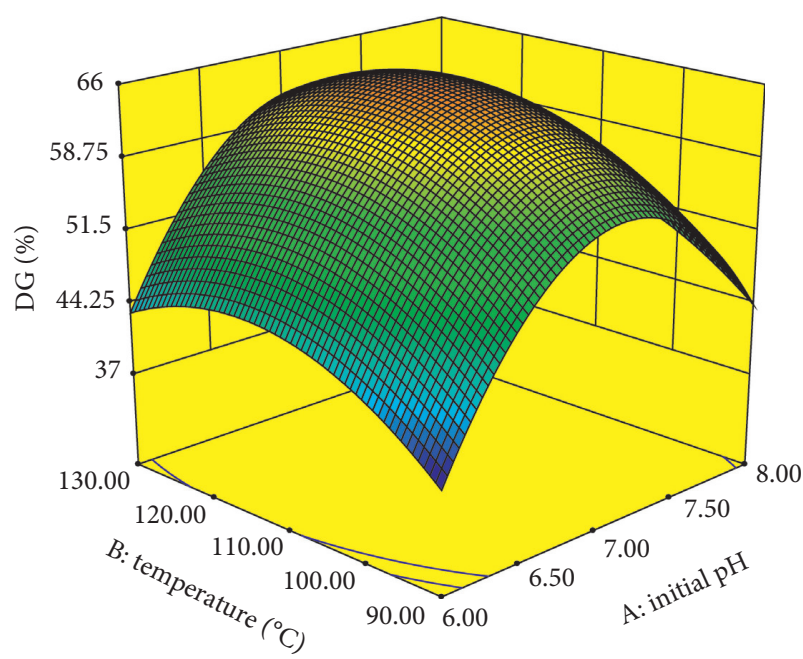

(a)

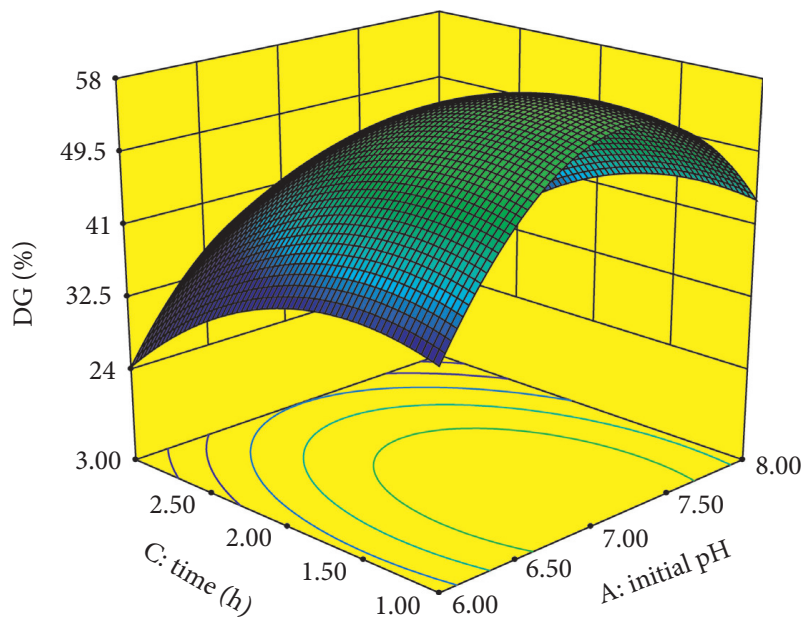

(c)

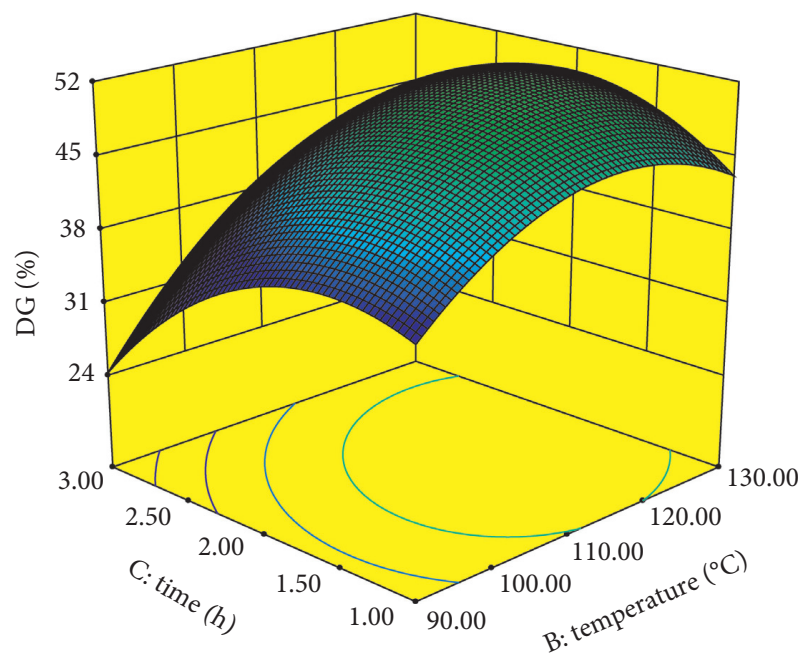

(e)

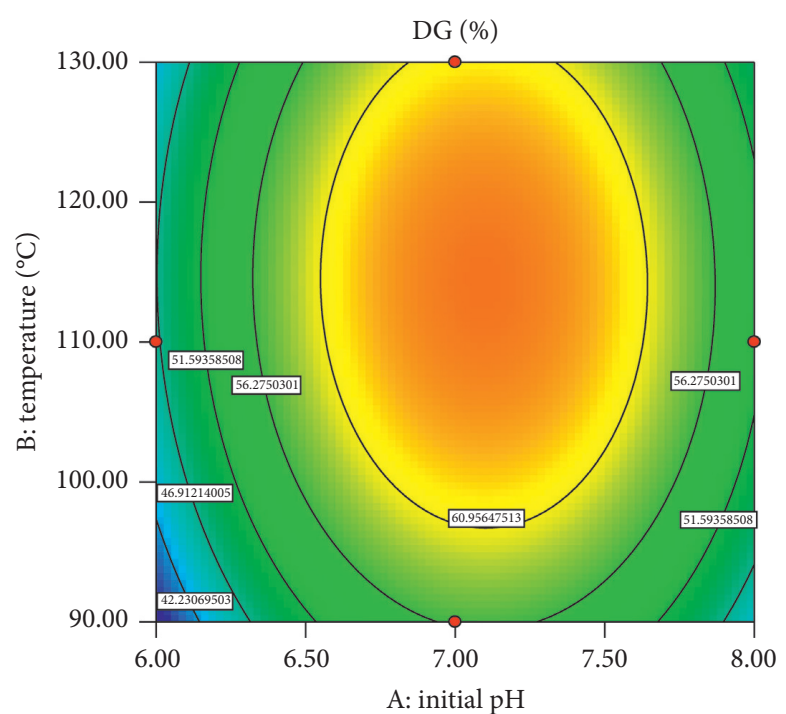

(b)

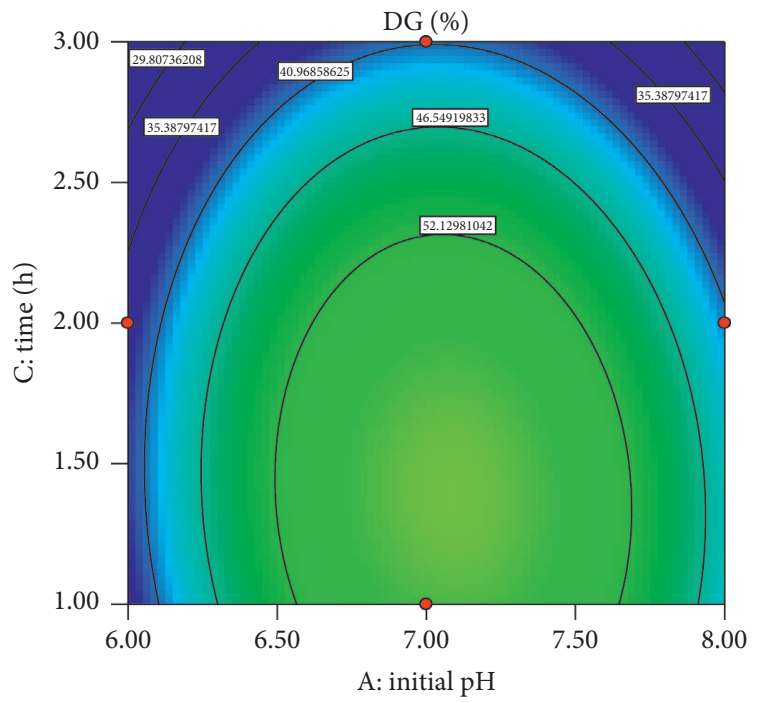

(d)

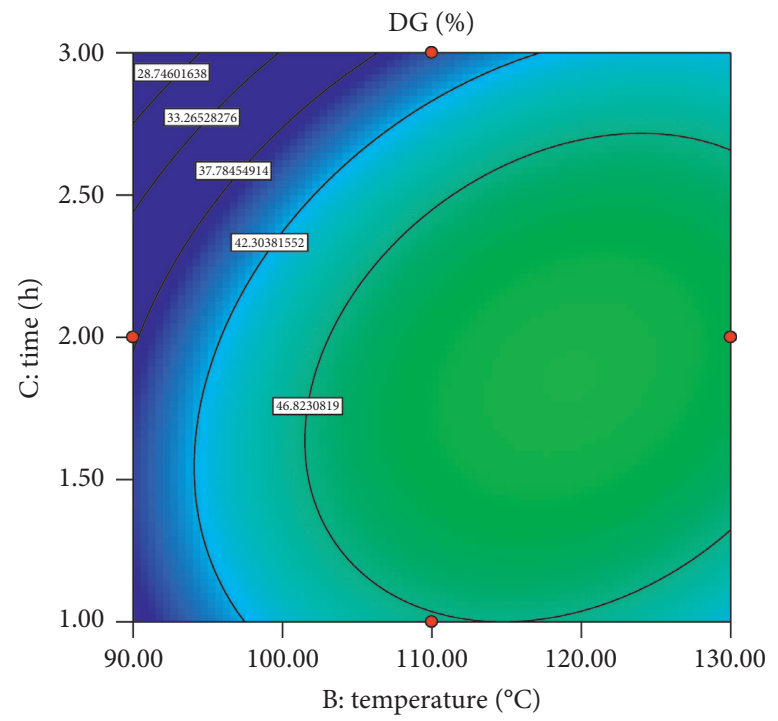

(f)

Figure 3: Response surface plots ( $\mathrm{a}, \mathrm{c}$, and e) and contour plots (b, $\mathrm{d}$, and $\mathrm{f})$ for the interactive effects of initial $\mathrm{pH}\left(x_{1}\right)$, temperature $\left(x_{2}\right)$, and time $\left(x_{3}\right)$ on the DG of the Maillard reaction. 


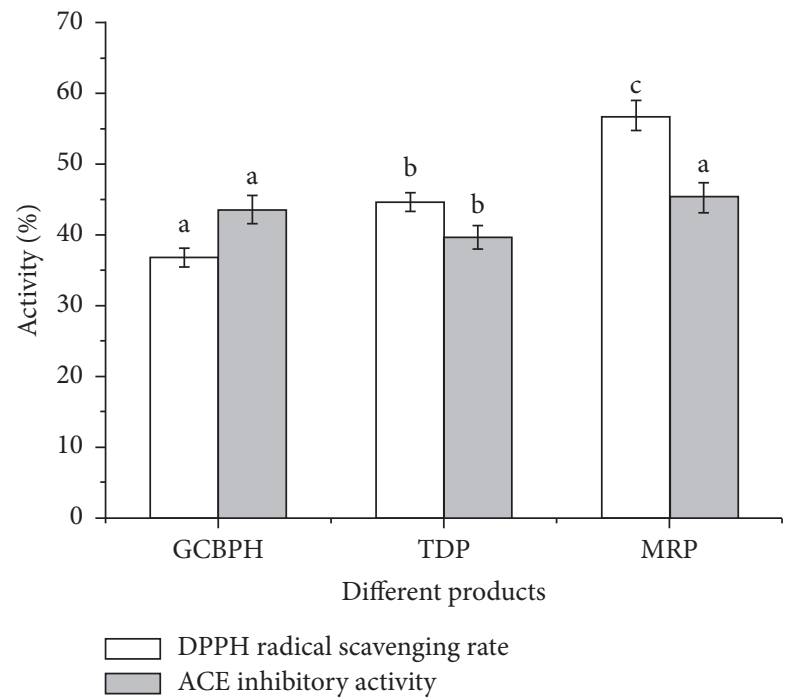

FIGURE 4: The DPPH radical scavenging rate and ACE inhibitory activity of GCBPH, TDP, and MRP. Means with different superscripts are significantly different $(p<0.05)$.

TABle 2: Amino acid composition of GCBPH, TDP, and MRP.

\begin{tabular}{|c|c|c|c|c|c|c|c|}
\hline \multirow{2}{*}{$\mathrm{AA}$} & \multirow{2}{*}{ Taste threshold } & \multicolumn{3}{|c|}{ TAA (mg/g) } & \multicolumn{3}{|c|}{ FAA $(\mathrm{mg} / \mathrm{g})$} \\
\hline & & GCBPH & TDP & MRP & GCBPH & TDP & MRP \\
\hline Pro & 300 & 87.65 & 84.18 & 68.17 & 6.38 & 5.95 & 2.87 \\
\hline $\operatorname{Trp}$ & - & 67.58 & 58.5 & 37.65 & 11.77 & 14.37 & 4.94 \\
\hline Leu & 90 & 38.35 & 32.94 & 22.65 & 28.19 & 24.28 & 14.25 \\
\hline Val & 150 & 17.97 & 11.7 & 8.55 & 12.04 & 6.63 & 5.62 \\
\hline Ile & 380 & 17.86 & 11.88 & 6.2 & 11.65 & 8.8 & 6.25 \\
\hline Phe & 150 & 18.52 & 17.23 & 13.16 & 13.54 & 14.13 & 6.38 \\
\hline Met & 30 & 14.87 & 12.75 & 9.57 & 9.05 & 9.48 & 6.58 \\
\hline His & 20 & 15.69 & 14.78 & 12.49 & 3.85 & 4.5 & 2.17 \\
\hline Glu & 5 & 64.51 & 59.45 & 33.84 & 12.18 & 13.12 & 5.85 \\
\hline Asp & 3 & 41.69 & 39.37 & 24.63 & 13.24 & 12.45 & 8.57 \\
\hline Arg & 10 & 34.16 & 28.38 & 21.29 & 17.65 & 14.83 & 11.49 \\
\hline Ala & 60 & 23.97 & 23.64 & 12.47 & 9.85 & 9.39 & 5.52 \\
\hline Gly & 110 & 28.48 & 24.17 & 19.5 & 5.83 & 6.22 & 3.45 \\
\hline Thr & 260 & 17.41 & 16.23 & 9.34 & 9.85 & 8.73 & 5.21 \\
\hline Ser & 150 & 9.2 & 8.64 & 5.62 & 6.01 & 6.08 & 4.87 \\
\hline Cys & - & 8.74 & 5.35 & 2.65 & 2.85 & 2.57 & 1.25 \\
\hline Lys & 50 & 42.85 & 40.79 & 24.69 & 24.65 & 23.62 & 9.51 \\
\hline Tyr & - & 16.65 & 15.35 & 9.49 & 11.74 & 11.46 & 4.02 \\
\hline Total & & 566.15 & 505.33 & 341.96 & 210.32 & 196.61 & 108.8 \\
\hline FAA ratio & & & & & 37.15 & 38.91 & 31.82 \\
\hline USAA & & 219.42 & 199.88 & 126.69 & 74.61 & 70.82 & 44.96 \\
\hline USAA ratio & & 38.76 & 39.55 & 37.05 & 35.47 & 36.02 & 41.32 \\
\hline
\end{tabular}

TAA represents total amino acids; FAA represents free amino acids; USAA represents umami-sweet taste amino acids, including Glu, Asp, Arg, Ala, Gly, Thr, and Ser.

identified as spoilage index. Benzaldehyde, with a relative content of $1.26 \%$, characterized by sweet and oily flavour, was reported in meat, bone meal, and sukiyaki flavour [29]. In alcohol, the 1-Octen-3-ol, identified and characterized as lipid oxidation product in fish oil, was an important flavour contributor due to its low odour threshold $[28,30]$. So far, 1Octen-3-ol as a predominant alcohol of hydrolysate (with relative amount of $4.10 \%$ ) revealed a pungent, soil, and fruit odour. It has been mentioned as the most distinct volatile characterizing fresh sardine and other fatty fish aromas [31]. Compared to short straight chain alcohols, long straight chain alcohols like 1-pentanol, 1-hexanol, and heptanol, as well as branched-chain alcohols like 1-Penten-3-ol and (Z)2-Octen-1-ol, contributed aroma to the products with relatively lower threshold value [32]. The 2,4-Di-tert-butylphenol was found to be the most abundant volatile (17.10\%) in the hydrolysate, which revealed a fermented sausage odour and contributed to antibiofilm activity [33]. Furans, 
TABLE 3: Volatile Compounds identified in GCBPH, TDP, and MRP by DHS GC-MS.

\begin{tabular}{|c|c|c|c|c|c|}
\hline & \multirow{2}{*}{ Compound } & \multirow{2}{*}{ Rta } & \multicolumn{3}{|c|}{ Percentage of total area (\%) } \\
\hline & & & GCBPH & TDP & MRP \\
\hline & Aldehydes & & & & \\
\hline 1 & 2-Methyl-propanal & 6.91 & & & 0.27 \\
\hline 2 & Butanal & 7.92 & & & 0.14 \\
\hline 3 & 2-Methyl-butanal & 8.69 & 1.56 & 2.12 & 1.86 \\
\hline 4 & 3-Methyl-butanal & 8.69 & 2.68 & 2.31 & 2.25 \\
\hline 5 & Pentanal & 10.21 & 1.68 & 1.44 & 0.72 \\
\hline 6 & 2-Butenal & 11.81 & & 0.18 & 0.21 \\
\hline 7 & Hexanal & 12.71 & 5.21 & 7.84 & 6.05 \\
\hline 8 & (E)-2-Pentenal & 13.13 & & & 0.19 \\
\hline 9 & Heptanal & 14.96 & & 0.33 & 0.33 \\
\hline 10 & 2-Hexenal & 15.8 & & 1.05 & 0.86 \\
\hline 11 & (Z)-2-Heptenal & 17.77 & & 2.27 & 2.41 \\
\hline 12 & 2-Methyl-2-heptenal & 18.27 & & & 0.43 \\
\hline 13 & Nonanal & 18.82 & 0.75 & 1.08 & 1.06 \\
\hline 14 & (E, E)-2,4-Hexadienal & 19.08 & & & 0.21 \\
\hline 15 & (E, E)-2,4-Heptadienal & 19.95 & & & 1.95 \\
\hline 16 & 3-(Methylthio)-propanal & 19.84 & 0.57 & 1.23 & 1.08 \\
\hline 17 & Furfural & 19.89 & 0.75 & 0.42 & \\
\hline 18 & Benzaldehyde & 20.91 & 1.26 & 1.71 & 1.56 \\
\hline 19 & (E,Z)-2,6-Nonadienal & 21.64 & & & 0.83 \\
\hline 20 & (E,E)-2,4-Nonadienal & 23.11 & & & 0.59 \\
\hline 21 & 4-Ethyl-benzaldehyde & 23.3 & 0.41 & 0.48 & 0.77 \\
\hline 22 & $(\mathrm{E}, \mathrm{E})-2,4$-Decadienal & 24.41 & & & 1.85 \\
\hline \multirow[t]{2}{*}{23} & $\alpha$-Ethylidene-benzeneacetaldehyde & 26.08 & & & 0.42 \\
\hline & Subtotal & & 14.87 & 22.46 & 26.04 \\
\hline 24 & Alcohol & & & & \\
\hline 25 & (E)-2-Pentenol & 13.92 & 1.22 & 0.10 & \\
\hline 26 & 1-Penten-3-ol & 14.55 & 3.25 & 2.89 & 2.18 \\
\hline 27 & 1-Pentanol & 16.31 & 2.70 & 3.04 & 2.35 \\
\hline 28 & 1-Hexanol & 18.05 & 2.45 & 2.24 & 1.95 \\
\hline 29 & 1-Octen-3-ol & 19.46 & 4.10 & 4.43 & 3.49 \\
\hline 30 & Heptanol & 19.59 & 2.11 & 1.71 & 1.52 \\
\hline 31 & 2-Ethyl-1-hexanol & 20.06 & 0.69 & 1.06 & 0.78 \\
\hline 32 & 1-Octanol & 20.99 & & & 0.88 \\
\hline 33 & (Z)-2-Octen-1-ol & 21.75 & 0.83 & 1.29 & 0.71 \\
\hline 34 & 6-Undecanol & 22.4 & & & 2.45 \\
\hline \multirow[t]{3}{*}{35} & Benzyl alcohol & 25.12 & & & 0.39 \\
\hline & Subtotal & & 17.35 & 16.77 & 16.70 \\
\hline & Ketone & & & & \\
\hline 36 & 2-Heptanone & 15.04 & & & 1.09 \\
\hline 37 & 3-Octen-2-one & 19.12 & 0.89 & & \\
\hline 38 & 2-Ethylidenecyclohexanone & 19.37 & 1.44 & & \\
\hline 39 & 3,5-Octadien-2-one & 21.46 & 7.67 & 4.88 & 1.51 \\
\hline 40 & 1H-Inden-1-one & 24.4 & & & 0.73 \\
\hline \multirow[t]{3}{*}{41} & 2-Ethyl-cyclopentanone & 28.47 & & 1.56 & 1.95 \\
\hline & Subtotal & & 10.00 & 6.44 & 5.29 \\
\hline & Hydrocarbon & & & & \\
\hline 42 & Hexamethyl-cyclotrisiloxane & 7.33 & 0.37 & 2.72 & 1.43 \\
\hline 43 & Octamethyl-cyclotetrasiloxane & 10.07 & 8.64 & 7.17 & 5.90 \\
\hline 44 & p-Xylene & 14.05 & & & 0.77 \\
\hline 45 & D-Limonene & 15.09 & & & 0.46 \\
\hline 46 & Tetradecane & 18.69 & 0.34 & & \\
\hline 47 & 1,3-Cyclooctadiene & 22.6 & 5.80 & 2.71 & \\
\hline 48 & Hexamethyl-cyclotrisiloxane & 23.42 & 0.34 & & \\
\hline \multirow[t]{2}{*}{49} & 2,6-Dimethyl-2,4,6-octatriene & 24.53 & & & 1.67 \\
\hline & Subtotal & & 15.48 & 12.60 & 10.23 \\
\hline & Furans & & & & \\
\hline 50 & 2-Ethyl-furan & 9.53 & 3.87 & 3.34 & 2.69 \\
\hline
\end{tabular}


TABLE 3: Continued.

\begin{tabular}{|c|c|c|c|c|c|}
\hline & \multirow{2}{*}{ Compound } & \multirow{2}{*}{ Rta } & \multicolumn{3}{|c|}{ Percentage of total area (\%) } \\
\hline & & & GCBPH & TDP & MRP \\
\hline 51 & 2-Pentyl-furan & 15.88 & 3.43 & 2.97 & 1.91 \\
\hline 52 & (E)-2-(1-Pentenyl)-furan & 17.04 & 1.76 & & \\
\hline 53 & cis-2-(2-Pentenyl)furan & 17.18 & 4.20 & 3.39 & 1.64 \\
\hline 54 & 2-Methyl-furan & 20.16 & & & 0.98 \\
\hline \multirow[t]{3}{*}{55} & (E)-2-(1-Pentenyl)-furan & 25.51 & 0.65 & 1.59 & 4.99 \\
\hline & Subtotal & & 13.90 & 11.29 & 12.20 \\
\hline & Phenol & & & & \\
\hline 56 & 4-Ethyl-phenol & 15.53 & 0.49 & & \\
\hline 57 & 2-Ethyl-phenol & 15.65 & & & 1.04 \\
\hline 58 & 4-(1-Methylpropyl)-phenol & 25.03 & 1.54 & & \\
\hline 59 & 2,6-Bis(1,1-Dimethylethyl)-4-(1-oxopropyl)phenol & 25.43 & 1.85 & & 0.34 \\
\hline \multirow[t]{3}{*}{60} & 2,4-Di-tert-butylphenol & 32.37 & 17.10 & 9.74 & 1.96 \\
\hline & Subtotal & & 20.98 & 9.74 & 3.34 \\
\hline & Esters & & & & \\
\hline 61 & Pentyl ester & 20 & & 1.05 & 1.11 \\
\hline 62 & Dioctyl phthalate & 20.99 & 2.64 & 1.79 & \\
\hline 63 & Benzyl benzoate & 24.89 & 3.25 & 2.86 & \\
\hline 64 & Bis(2-Ethylhexyl)ester & 27.27 & & & 0.61 \\
\hline 65 & Butylisohexylester & 29.28 & & 1.71 & 2.29 \\
\hline \multirow[t]{3}{*}{66} & Methyl palmitate & 30.44 & 1.52 & 0.56 & \\
\hline & Subtotal & & 7.41 & 7.97 & 4.01 \\
\hline & Pyrazine & & & & \\
\hline 67 & Methyl-pyrazine & 16.83 & & 5.33 & 4.12 \\
\hline 68 & 2,6-Dimethyl-pyrazine & 17.86 & & & 0.93 \\
\hline 69 & 3-Ethyl- 2,5-Dimethyl-pyrazine & 19.75 & & & 1.85 \\
\hline 70 & 2,5-Dimethyl-3-Propyl-pyrazine & 20.7 & & & 0.87 \\
\hline \multirow[t]{3}{*}{71} & 2-Butyl-3,5-Dimethyl-pyrazine & 22.53 & & & 2.87 \\
\hline & Subtotal & & & 5.33 & 10.63 \\
\hline & Others & & & & \\
\hline 72 & Butanamide & 13.52 & & & 3.22 \\
\hline 73 & 1,3 -Diazine & 15.72 & & & 0.81 \\
\hline 74 & 2-Chloro-4-(4-Methoxyphenyl)-6-(4-Nitrophenyl)pyrimidine & 16.56 & & 4.73 & 3.32 \\
\hline 75 & 4-Methylthiazole & 22.26 & & 1.31 & 1.87 \\
\hline \multirow[t]{3}{*}{76} & 2-Methylpiperidine & 28.47 & & 1.36 & 2.35 \\
\hline & Subtotal & & & 7.40 & 11.56 \\
\hline & Total & & 100 & 100 & 100 \\
\hline
\end{tabular}

providing green bean and butter flavours, could be generated from sugar caramelization and carbohydrate degradation [28] and had been identified in fish oil and fish sauce [30, 34]. Esters were identified in contributing to pleasant seafood aromas in general [31].

During the thermal degradation process, the flavour compounds of sample were 40 kinds, with eleven new substances added in aldehydes, pyrazine, and other categories, and eight substances disappeared in ketone, hydrocarbon, furans, and phenol. In addition to taste-eliciting compounds such as peptides and amino acids, aroma compounds were generated by Maillard browning reaction, Strecker degradation, and so forth [35]. The volatile compounds identified in the MRP with 62 kinds are presented in Table 3, which included 22 aldehydes, 10 alcohol, 4 ketone, 5 hydrocarbon, 5 furans, 3 phenol, 3 esters, 5 pyrazine, and 5 others. The volatile aldehydes class contributed the major volatiles in the MRP, which were of relative higher amounts $26.04 \%$, which were much higher than those of GCBPH. Straight and branched-chain aldehydes generally provided herbaceous, grassy, and pungent aromas, while unsaturated aldehydes were linked with vegetal and fishy notes and each of these compounds possesses its own specific odours. For instance, 2-Methyl-Propanal (value of $0.27 \%$ ) gave a pungent smell and fishy and grassy aroma was provided by hexanal (value of 6.05\%). Moreover, 2-Methyl-butanal (value of $1.86 \%$ ) and 3-Methyl-butanal (value of $2.25 \%$ ) produced nutty odours. Furthermore, unsaturated n-2alkenals, such as (Z)-2-Heptenal, (E, E)-2,4-Heptadienal, and (E, E)-2,4-Decadienal, might play a more important role in the formation of species-specific flavour [36]. The volatile ketones were most likely the products of lipid and/or amino acid degradation. Only four ketone compounds were detected in the MRP samples, which may contribute to the cheesy odour of MRP with relative lower total amount. All of these factors contributed to the overall aroma of the MRP. The pyrazines, furans, and esters were the most desirable compounds in food products to enhance the aroma of the products. Compared with volatile components in GCBPH, the compounds in MRP increased from 8 to 13 kinds. The 
relative content of pyrazine in the volatile components was $10.63 \%$. Pyrazine, due to its large size and low taste threshold, was considered to be a significant volatile flavour in many heat-processed products and gave a pleasant nutty and baking flavour. The 4-Methylthiazole in the sulfurcontaining compound accounted for $1.87 \%$ of the total amount, which was regarded as a perfume intermediate that might come into being during the process of Maillard reaction consisting of amino acids and sugars or compounds containing carbonyl groups. Compared to that of GCBPH and TDP, MRP contained more kinds of flavour volatile compounds of aldehydes, alcohol, ketone, pyrazine, and others. Maillard reaction was then indicated to be capable of perfecting the flavour and aroma of the hydrolysate from grass carp protein.

\section{Discussion}

In this paper, the fish bone of common species of fish, grass carp, was used as a sample to investigate its high value utilization using different methods. The preparation of bioactive peptide and flavour compounds by enzymatic method was an effective method to make full use of protein resources. However, it still has a relatively low biological activity and low content of flavour compounds. Many researches showed that Maillard reaction not only can increase the bioactivities but also can improve the flavour of protein hydrolysate $[15,22]$. As a consequence, the Maillard reaction of hydrolysate from grass carp bone protein was used for preparation of bioactive compounds and identification of characteristic flavour compounds using thermal degradation method as the positive control. Compared with the thermal degradation methods, Maillard reaction probably generated more compounds and substances with higher DPPH radical scavenging activity and ACE inhibitory activities. However, thermal degradation methods significantly reduced the ACE inhibitory activity of protein hydrolysate in contrast to those of GCBPH and MRP. The reason might be that thermal treatment degraded some of the active proteins or peptides into inactive fragment.

The flavour and taste quality of foods are the most important factors affecting consumers' choice and acceptance. In terms of aquatic products, the flavour, as the main factor, determines its quality to a great extent. These flavours include not only the soft and pleasant smell but also the unpleasant odour. In the products related to protease hydrolysis, some peptides with sensory properties, such as sweet peptides, bitter peptides, acid peptides, salty peptides, and flavour-enhancing peptides, play a vital role in improving sensory characteristics and flavour enhancement of hydrolysates. Therefore, the proportion of umami-sweet taste amino acids in free amino acids directly affects the flavour and quality of hydrolysates. In this experiment, Maillard reaction can lead to the increase of the umamisweet taste amino acids ratio in free amino acids and improve the flavour by increasing the volatile compounds. It indicated that Maillard reaction was an effective way to process fish bone, which provided a new direction for the application of fish bone.
In conclusion, compared to grass carp bone protein hydrolysate and its thermal degradation products, Maillard reaction significantly increased the DPPH radical scavenging activity of hydrolysate and the proportion and variety of umami-sweet taste amino acid in total free amino acids of grass carp protein hydrolysate. These findings suggested that fish bone protein hydrolysate could be effectively prepared by enzymolysis and Maillard reaction could improve its utilization by increasing antioxidant activity and flavours.

\section{Data Availability}

The data supporting the results of this study are available within the paper or are available from the corresponding author upon reasonable request.

\section{Conflicts of Interest}

The authors declare that they have no conflicts of interest.

\section{Acknowledgments}

The authors would like to acknowledge the National Natural Science Foundation of China (no. 31701538), Youth Science Fund Project of Natural Science Foundation of Hebei Province (no. C2019406071), the Natural Science Foundation of the Jiangsu Higher Education Institutions of China (17KJB550001), and Program Sponsored for Scientific Innovation Research of College Graduate in Jiangsu Province, China (KYCX18_2279).

\section{References}

[1] H. Zhan, X. Liu, S. Jia, and Y. Luo, "Antimicrobial effects of cinnamon bark oil on microbial composition and quality of grass carp (Ctenopharyngodon idellus) fillets during chilled storage," Food Control, vol. 82, pp. 316-324, 2017.

[2] J. Xiao and L. Niu, "Antilisterial and antioxidant activities of neutrase-treated grass carp proteins and their effects on the storage and quality properties of fresh noodle," Journal of Food Processing and Preservation, vol. 40, no. 6, pp. 14211428, 2016.

[3] D. Yu, Q. Jiang, Y. Xu, and W. Xia, "The shelf life extension of refrigerated grass carp (Ctenopharyngodon idellus) fillets by chitosan coating combined with glycerol monolaurate," International Journal of Biological Macromolecules, vol. 101, pp. 448-454, 2017.

[4] H. G. Kristinsson and B. A. Rasco, "Biochemical and functional properties of Atlantic salmon (Salmo salar) muscle proteins hydrolyzed with various alkaline proteases," Journal of Agricultural and Food Chemistry, vol. 48, no. 3, pp. 657666, 2000.

[5] J. Ren, M. Zhao, J. Shi et al., "Optimization of antioxidant peptide production from grass carp sarcoplasmic protein using response surface methodology," LWT-Food Science and Technology, vol. 41, no. 9, pp. 1624-1632, 2008.

[6] J. Wasswa, J. Tang, X. Gu, and X. Yuan, "Influence of the extent of enzymatic hydrolysis on the functional properties of protein hydrolysate from grass carp (Ctenopharyngodon idella) skin," Food Chemistry, vol. 104, no. 4, pp. 1698-1704, 2007.

[7] X. Li, Y. Luo, H. Shen, and J. You, "Antioxidant activities and functional properties of grass carp (Ctenopharyngodon idellus) 
protein hydrolysates," Journal of the Science of Food and Agriculture, vol. 92, no. 2, pp. 292-298, 2012.

[8] S. Wang, L.-M. Lin, Y.-N. Wu et al., "Angiotensin I converting enzyme (ACE) inhibitory activity and antihypertensive effects of grass carp peptides," Food Science and Biotechnology, vol. 23, no. 5, pp. 1661-1666, 2014.

[9] X. Guo, X. Han, Y. He, H. Du, and Z. Tan, "Optimization of enzymatic hydrolysis for preparation of shrimp flavor precursor using response surface methodology," Journal of Food Quality, vol. 37, no. 4, pp. 229-236, 2014.

[10] H. Hu, B. Li, and X. Zhao, "Enzymatic hydrolysis of defatted mackerel protein with low bitter taste," Journal of Ocean University of China, vol. 10, pp. 85-92, 2011.

[11] R. Liyt, E. Daukšas, E. Falch, I. Storr, and T. Rustad, "Characteristics of protein fractions generated from hydrolysed cod (Gadus morhua) by-products," Process Biochemistry, vol. 40, pp. 2021-2033, 2005.

[12] X. M. Feng, X. H. Yang, W. C. Xie et al., "Optimization of enzymatic hydrolysis of white shrimp (Penaeus vannamei) head Using response surface methodology," Food Science, vol. 30, pp. 66-70, 2009.

[13] Y. Li, F. Zhong, W. Ji, W. Yokoyama, C. F. Shoemaker, and $\mathrm{S}$. Zhu, "Functional properties of Maillard reaction products of rice protein hydrolysates with mono-, oligo- and polysaccharides," Food Hydrocolloids, vol. 30, pp. 53-60, 2013.

[14] C. Kouakou, J.-P. Bergé, R. Baron, L. Lethuaut, C. Prost, and C. Mireille, "Odor modification in salmon hydrolysates using the Maillard reaction," Journal of Aquatic Food Product Technology, vol. 23, pp. 453-467, 2014.

[15] G. Su, Z. Lin, C. Cui, Y. Bao, J. Ren, and M. Zhao, "Characterization of antioxidant activity and volatile compounds of Maillard reaction products derived from different peptide fractions of peanut hydrolysate," Food Research International, vol. 44, pp. 3250-3258, 2011.

[16] S. Nilsang, S. Lertsiri, M. Suphantharika, and A. Assavanig, "Optimization of enzymatic hydrolysis of fish soluble concentrate by commercial proteases," Journal of Food Engineering, vol. 70, pp. 571-578, 2005.

[17] J. J. Guan, A. Y. Qiu, X. Y. Liu, Y. F. Hua, and Y. H. Ma, "Microwave improvement of soy protein isolate-saccharide graft reactions," Food Chemistry, vol. 97, pp. 577-585, 2006.

[18] F. Nasrollahzadeh, M. Varidi, A. Koocheki, and F. Hadizadeh, "Effect of microwave and conventional heating on structural, functional and antioxidant properties of bovine serum albumin-maltodextrin conjugates through Maillard reaction," Food Research International, vol. 100, pp. 289-297, 2017.

[19] C. Zhou, H. Ma, Q. Ding et al., "Ultrasonic pretreatment of corn gluten meal proteins and neutrase: effect on protein conformation and preparation of ACE (angiotensin converting enzyme) inhibitory peptides," Food and Bioproducts Processing, vol. 91, pp. 665-671, 2013.

[20] M. R. Rhyu and E. Y. Kim, "Umami taste characteristics of water extract of Doenjang, a Korean soybean paste: lowmolecular acidic peptides may be a possible clue to the taste," Food Chemistry, vol. 127, pp. 1210-1215, 2011.

[21] V. Kachrimanidou, N. Kopsahelis, A. Chatzifragkou, S. Papanikolaou, and A. A. Koutinas, "Utilisation of byproducts from sunflower-based biodiesel production processes for the production of fermentation feedstock," Waste and Biomass Valorization, vol. 4, pp. 529-537, 2013.

[22] M. Yu, S. He, M. Tang, Z. Zhang, Y. Zhu, and H. Sun, "Antioxidant activity and sensory characteristics of Maillard reaction products derived from different peptide fractions of soybean meal hydrolysate," Food Chemistry, vol. 243, pp. 249-257, 2018.

[23] Y. Yamasaki and K. Maekawa, "A peptide with delicious taste," Agricultural and Biological Chemistry, vol. 42, pp. 1761-1765, 1978.

[24] M. Behrens, W. Meyerhof, C. Hellfritsch, and T. Hofmann, "Sweet and umami taste: natural products, their chemosensory targets, and beyond," Angewandte Chemie International Edtion (in English), vol. 50, pp. 2220-2242, 2011.

[25] Z. Yu, H. Jiang, R. Guo et al., "Taste, umami-enhance effect and amino acid sequence of peptides separated from silkworm pupa hydrolysate," Food Research International, vol. 108, pp. 144-150, 2018.

[26] X. B. Dong, L. Xia, C. H. Zhang et al., "Development of a novel method for hot-pressure extraction of protein from chicken bone and the effect of enzymatic hydrolysis on the extracts," Food Chemistry, vol. 157, pp. 339-346, 2014.

[27] W. Kolanowski, D. Jaworska, and J. Weissbrodt, "Importance of instrumental and sensory analysis in the assessment of oxidative deterioration of omega-3 long-chain polyunsaturated fatty acid-rich foods," Journal of the Science of Food \& Agriculture, vol. 87, pp. 181-191, 2010.

[28] J. Iglesias, I. Medina, F. Bianchi, M. Careri, A. Mangia, and M. Musci, "Study of the volatile compounds useful for the characterisation of fresh and frozen-thawed cultured gilthead sea bream fish by solid-phase microextraction gas chromatography-mass spectrometry," Food Chemistry, vol. 115, pp. 1473-1478, 2009.

[29] C. Sonklin, N. Laohakunjit, and O. Kerdchoechuen, "Physicochemical and flavor characteristics of flavoring agent from mungbean protein hydrolyzed by bromelain," Journal of Agricultural and Food Chemistry, vol. 59, pp. 8475-8483, 2011.

[30] K. Hartvigsen, P. Lund, L. F. Hansen, and G. H. Holmer, "Dynamic headspace gas chromatography/mass spectrometry characterization of volatiles produced in fish oil enriched mayonnaise during storage," Journal of Agricultural and Food Chemistry, vol. 48, pp. 4858-4867, 2000.

[31] K. Grigorakis, I. Giogios, A. Vasilaki, and I. Nengas, “Effect of the fish oil, oxidation status and of heat treatment temperature on the volatile compounds of the produced fish feeds," Animal Feed Science \& Technology, vol. 158, pp. 73-84, 2010.

[32] A. Giri, K. Osako, and T. Ohshima, "Identification and characterisation of headspace volatiles of fish miso, a Japanese fish meat based fermented paste, with special emphasis on effect of fish species and meat washing," Food Chemistry, vol. 120, pp. 621-631, 2010.

[33] S. Kalaichelvan, N. Sundaraganesan, O. Dereli, and U. Sayin, "Experimental, theoretical calculations of the vibrational spectra and conformational analysis of 2,4-di-tert-butylphenol," Spectrochimica Acta Part A Molecular and Biomolecular Spectroscopy, vol. 85, pp. 198-209, 2012.

[34] J. S. Elmore, M. M. Campo, M. Enser, and D. S. Mottram, "Effect of lipid composition on meat-like model systems containing cysteine, ribose, and polyunsaturated fatty acids," Journal of Agricultural and Food Chemistry, vol. 50, pp. 1126-1132, 2002.

[35] M. X. Zhang, X. C. Wang, Y. Liu, X. L. Xu, and G. H. Zhou, "Isolation and identification of flavour peptides from Puffer fish (Takifugu obscurus) muscle using an electronic tongue and MALDI-TOF/TOF MS/MS," Food Chemistry, vol. 135, pp. 1463-1470, 2012. 
[36] X. Shi, X. Zhang, S. Song, C. Tan, C. Jia, and S. Xia, "Identification of characteristic flavour precursors from enzymatic hydrolysis-mild thermal oxidation tallow by descriptive sensory analysis and gas chromatography-olfactometry and partial least squares regression," Journal of Chromatography B-Analytical Technologies in the Biomedical and Life Sciences, vol. 913-914, pp. 69-76, 2013. 